\title{
The Influence of Services Quality to Domestic Tourists' Loyalty through Domestic Tourists' Satisfaction at Mount Bromo Tourism in East Java Indonesia
}

\author{
Rizki Amelia ${ }^{1}$ and Santi Palupi ${ }^{2}$ \\ ${ }^{1}$ Burapha University, Chonburi, Thailand and \\ Graduate School Trisakti Institute of Tourism, Jakarta, Indonesia \\ ${ }^{2}$ Podomoro University, Jakarta, Indonesia
}

Corresponding author: rizqiamelia13@gmail.com

\begin{abstract}
ARTICLE INFO ABSTRACT
Received

20 March 2016

Accepted

30 August 2016

Available online

15 September 2016

This study was aimed to analyze the influence of quality of tour services to domestic tourists' loyalty at Mount Bromo East Java. The number of respondents were 100 domestic tourists who have visited Mount Bromo at least 2 times. Three variables were used namely, quality of service as an independent variable, satisfaction as an intervening variable, and loyalty as the dependent variable. Path analysis was used to analyze the data. The results showed that: i) Quality of tour services significantly influenced satisfaction of domestic tourists at Mount Bromo, ii) Quality of tour services also significantly influenced domestic tourists' loyalty, and iii) Customers satisfaction significantly influenced domestic tourists' loyalty at Mount Bromo. The results indicated that there were positive perception of domestic tourists on the quality of tour services, satisfaction and loyalty at Mount Bromo.
\end{abstract}

Keywords: quality of services, domestic tourists, satisfaction, loyalty

\section{Introduction}

Services sector today has seen a dramatic increase compared to the previous decade. This is evident from the sector's contribution to the world economy has now dominate about two-thirds. In Europe, for example, this sector has contributed as much as $60 \%$ of GDP, while in Indonesia reached almost $30 \%$. Contributions can be seen in terms of profit and its ability to absorb most of the energy supply work (Lupiyoadi, 2006, p. 2). For example, one of the services sector in Indonesia that developed is the tourism industry which has provided contribute to improving the economy in Indonesia. As one of the industry's most popular and biggest in the world grows quickly and http://ojs.unud.ac.id/index.php/eot even in many countries including Indonesia, tourism have become the leading sectors (non-oil) in a growing economy in order to contribute in improving the performance of the structure of the economy, in this case include expanding employment opportunities, improving local revenue (PAD), an increase in foreign exchange earnings and investments. Tourism in Indonesia has been regarded as one of the important economic sector. In fact, this sector is expected to become the number one foreign exchange earner. The contribution increases with increasing the amount of travelers who come to visit tourist place contained and dispersed in Indonesia. Data World Tourism Organization (WTO), shows that visits of the average receipts 
visit tourists, Indonesia is on the top ranks of the 10 largest countries. The most important factor in enhancement number of tourists is the provision of infrastructure and transport qualified to expand access, in addition to policy implementation rational price on the management of services supporting tourism, either public and private acts as a support of increasing success traveler confidence in the products of tourism services (Taroepratjeka, 2000).

Indonesia is made up of thousands of islands spread extends from the west end to the east end, is profitable. Aside from scattered islands separated by many straits, Indonesia is also famous for its many beautiful place landscape and contains a lot of historical value, it is a lot invite the tourists (both foreign tourists and domestic tourists)for a visit. From year to year the number of tourists is increasing, especially during this current development, the Indonesian tourism is being excited and encouraged to occupy the position of one of "the big seven" foreign exchange. Efforts to increase the tourist flow in order to do maturely to improve service quality and address the various problems encountered in this field. If this is not done then the increase will harm Indonesia, because tourists are not satisfied with theservices rendered and cause damage to the image of Indonesian tourism.

East Java is a province in the eastern part of Java Island, Indonesia. East Java Province has 229 islands with a land area of $47130.15 \mathrm{~km} 2$ and a sea area of $110,764.28 \mathrm{~km} 2$. This region stretches between $111^{\circ} 0{ }^{\prime} \mathrm{E}-114^{\circ} 4^{\prime} \mathrm{BT}$ and $7^{\circ}$ 12 'LS - $8^{\circ} 48^{\prime}$ South Latitude. East Java is one of the potential tourist destinations, almost every regency / city has an attractive tourist destination. Tourist destination in East Java includes cultural tourism, historical tourism and nature. East Java is also one part of the tourism development plan national is one of the areas with tourism potential is extraordinary when compared to the surrounding provinces. Bromo tourism area lies at an altitude of 2,300 meters above sea surface with an area of 5,290 hectares, and is flanked by four counties partsof the provincial government of East Java, which is Malang, Probolinggo, Pasuruan and Lumajang. There are four entrances to reach the area Bromo, the Village Cemorolawang (Probolinggo), Village Wonokitri (Pasuruan), Village Ngadas Tumpang (Malang), and Village Burno (Lumajang). Bromo as one of the attractions located in East Java which is part of the Bromo Tengger Semeru National Park. Famous with the caldera or crater sea of sand and exotic, and views sunrise (Bromo Sunrise Tour) very beautiful that can be enjoyed by tourists at Mount Penanjakan. The Tengger caldera in administration governments there in Probolinggo. The nearby village of Caldera Tengger is Cemorolawang.

Quality of service is vital for companies, especially for companies that sell services such as industrial tourism. Therefore, managers should be able to get information accurate information on tourist satisfaction so that managers can adopt policiesto develop strategies to improve and enhance the quality services. Customer satisfaction is the key to the success of a company, it was given by satisfied consumers, then consumers will be loyal. Earned consumer loyalty for their konmbinasi of satisfaction and complaint. Satisfaction is feeling happy or disappointed someone who emerged after comparing the performance (yield) of products considered against the expected performance (Kotler \& Keller, 2007, p. 177). Consumer satisfaction as the fulfillment of pleasure. Understanding customer satisfaction in loyalty research conceptualized as a comprehensive evaluation of consumer experiences with service providers, not just the satisfaction rating based on specific transactions 
(Oliver, 1999; Moliner et al., 2007; Han and Back, 2008). According to Oliver and DeSarbo (1988) Satisfaction is the comparison of performance with expectations, but according to Oliver (1999) definition is based on what has been done by the consumer rather than on psychological meaning therefore Oliver (1999) defines satisfaction as the fulfillment of pleasure. Sense of satisfaction in loyalty research conceptualized as a comprehensive evaluation of consumer experiences with service providers, not just the satisfaction rating based on specific transactions (Hennig-Thurau and Klee, 1997; Gwinner, Gremler and Bitner, 1998; Gustafsson and Jhonson, 2000; Harris and Goode, 2004).

Customer loyalty is also very important to maintain survival of business activities. Customer faithful is that they are very satisfied with the products and specific services, so as to have the enthusiasm to introduce it to anyone they know. Then on the next stage of loyal customers it will expand the loyalty on other products made in the same manufacturer. Kotler (2003) states that loyalty is the customer who makes a purchase with increasing the percentage of a particular company rather than another company. Camarero (2007) declare loyalty is the result of activities involving interaction and repetitive purchases of consumers. Experts agree loyalty is an integral part of doing business. Related to this, experts are trying hard to find a precise definition of customer loyalty and the factors that lead to customer loyalty. Better understanding of consumer loyalty, will help the company to follow up various issues related to loyalty. Perceived service quality is a determinant of loyalty and commitment (Gounaris, Stathakopoulos and Athanassopoulos, 2003). Customers satisfaction effect on loyalty, so that it can said that the development of quality of service for fulfillment travelers will ultimately boils down to loyalty. The statement also supported by the results of research Bloemer, De Ruyter and Peeters (1998) shows that directly affect service quality and not direct loyalty through satisfaction. Lupiyoadi (2013, p. 91) also states that "the basis for a real loyalty lies in customer satisfaction, where quality of service into the main input. Customers who are highly satisfiedor even those who enjoyed the service tends to be a loyal supporter company". Build loyalty is a strategic policy for the companybecause companies view customer loyalty, which is part of the the company's strategy in the face of competitors and connecting companies with the market (consumers). Loyalty is needed as an element in competitive marketing strategy. In particular in the face of conditions an increasingly competitive market, companies often realize the future their customer loyalty.

\section{Research objectives:}

The objectives of this study were to analyze influence of quality of tour services to domestic tourists' satisfaction at Mount Bromo, to analyze influence of quality of tour services to domestic tourists' loyalty at Mount Bromo and to analyze influence of domestic tourists' satisfaction to domestic tourists' loyalty at Mount Bromo.

\section{Methodology}

Research was undertaken at Mount Bromo East Java. The number of respondents were 100 domestic tourists who have visited Mount Bromo at least 2 times. Three variables were used namely, quality of service as an independent variable, satisfaction as an intervening variable, and loyalty as the dependent variable. Data were collected by survey method by using questionnaires and deepth interview. Path analysis was used to analyze the data. 


\section{Validity test}

Validity test aims to determine the extent of the validity of the data obtained from the questionnaire. Test the validity as a measurement in this study, using the product moment correlation of Pearson's, that is by correlating each question with a total score, then the correlation results are compared with the number of critical significance level of $5 \%$, using the formula, (Prayitno, 2010). Measurements conducted by examining the validity of the significance level of productPearson's moment. A variable is said to be valid, if the variable provides significant value $<5 \%$.

$$
\begin{aligned}
& r=\frac{n \sum X Y-\left(\sum X\left(\sum Y\right)\right)}{\sqrt{n \sum X^{2}}-\left(\sum X\right)^{2}{\sqrt{n \sum Y^{2}}-\left(\sum Y\right)^{2}}^{\text {where: }}} \\
& \mathrm{r}=\text { The correlation coefficient, } \\
& \mathrm{X}=\text { Score questions, } \\
& \mathrm{Y}=\text { Total Score, } \\
& \mathrm{n}=\text { Number of samples. }
\end{aligned}
$$

\section{Reliabilty Test}

Reliability test is used to test the ability of a result relatively consistent measurements when the measurement is repeated twice or more (Prayitno, 2010:75). Reliability concentrate on the problem of measurement accuracy and the result. In other words, the reliability shows how much control measures on the same subject. Tests measuring tool constraints in using research tools reliability method of alpha $(\alpha)$ is the method of Cronbach (Prayitno, 2010:75). Measurement is done by testing the reliability statistics CronbachAlpha. A variable is said to be reliable if these variables gives Cronbach Alpha values $>0.60$.

where:

$$
\alpha=\frac{k r}{1+(k-1) r}
$$

$\alpha=$ coefficient of reliability,

$r=$ the average correlation coefficient between variables,

$\mathrm{k}=$ number of independent variables in the equation.

\section{Path Analysis}

Before the path analysis, the data obtained from the questionnaire needin the first test normality with normality test. Normality Test Data conducted to determine whether the data obtained normal distribution or no. Normality test conducted on samples was done by using the Kolmogorov-Smirnov test to establish the degree of confidence $(\alpha)$ by $5 \%$. This test is performed on each variable with the proviso that if individually each variable to meet the assumptions of normality, then simultaneously these variables can also be found to comply with the assumptions normality (Prayitno, 2010:71). Testing criterias with a view scale KolmogorovSmirnov test are;

1. If the significance of $>0.05$ means normally distributed

2. If significance $<0.05$ means not normally distributed

Model path analysis were used in this studycan be described in structural equation as follows;

$$
\begin{aligned}
& \text { Sat }=\beta_{0}+\beta_{1} Q S+\varepsilon_{1} \\
& \text { Loy }=\beta_{0}+\beta_{1} Q S+\beta_{2} S A T+\varepsilon_{2} \\
& \text { where: } \\
& \mathrm{QS}=\text { quality of service } \\
& \text { Loy }=\text { loyalty, } \\
& \text { Sat }=\text { satisfaction, } \\
& \varepsilon_{1} \varepsilon_{2}=\text { confounding variables. }
\end{aligned}
$$

\section{t- Test}

Testing the t-test was used to determine the effect of quality travel services to loyalty through satisfaction of tourists in places Bromo Tourism. The formula is:

$$
\begin{aligned}
& \qquad t=\frac{b i}{S e(b i)} \\
& \text { where: } \\
& \mathrm{t}=\text { test significant correlation } \\
& \text { number, } \\
& \text { bi }=\text { regression coefficient, } \\
& \text { Se (bi) = standard error of the correlation } \\
& \text { coefficient. }
\end{aligned}
$$




\section{Results and Discussion}

Most of respondents were ranged between 17-25 years, followed by 26-34 years. Most of them were male. From education, the results showed that most of respondents were senior high school followed by diploma and bachelor. From job experience, most of them were students, followed by servants and private employees. Most of respondents have visited Bromo 2-3 times during the period of 2011-2016, followed by $4-5$ times and 6-7 times.

Validity test showed that alpha Cronbach coefficient were $0.731,0.720$, and $0.700(>0.60)$ indicated that the data obtained were reliable.

Results of path aanalyses showed that the probability value or significance for each variable is greater than 0.05 , so it can be stated that the data were normally distributed, see Table 1.

Table 1

Path Analysis Results

\begin{tabular}{|c|c|c|c|c|c|c|c|c|c|}
\hline \multicolumn{2}{|c|}{ Standerdized } & \multirow{2}{*}{$t_{\text {value }}$} & & \multirow{2}{*}{$t_{\text {table }}$} & \multirow{2}{*}{ Sig. } & & \multirow{2}{*}{$A$} & \multirow{2}{*}{ Result } & \multirow[t]{2}{*}{$r^{2}$} \\
\hline Path & Beta $\beta$ & & & & & & & & \\
\hline $\mathrm{QS} \rightarrow \mathrm{SAT}$ & 0,693 & 9,521 & $>$ & 1,984 & 0,000 & $<$ & 0,05 & Significant & 0,480 \\
\hline $\mathrm{QS} \rightarrow \mathrm{LOY}$ & 0,503 & 5,754 & $>$ & 1,984 & 0,000 & $<$ & 0,05 & Significant & 0,253 \\
\hline $\mathrm{SAT} \rightarrow \mathrm{LOY}$ & 0,374 & 3,995 & $>$ & 1,984 & 0,000 & $<$ & 0,05 & Significant & 0,140 \\
\hline$\varepsilon 1$ & 0,554 & - & - & - & - & - & - & - & - \\
\hline$\varepsilon 2$ & 0,704 & - & - & - & - & - & - & - & - \\
\hline
\end{tabular}

Based on the path coefficients in Table 1, the equation that can be formed as follows;

$\mathrm{SAT}=-0,419+0,693 \mathrm{QS}+\varepsilon 1$.

$\mathrm{LOY}=0.849+0.503 \mathrm{QS}+0.374$

$\mathrm{SAT}+\varepsilon 2$

QS influence SAT significantly affect the views from the Sig $(0,000)$ $<0,05$.

QS affect the SAT can be seen from the coefficient of determination $\left(r^{2}\right)$ or beta coefficient $(\beta)$ of the table can be seen $\beta=$ 0,693 so that $\beta=0,693^{2}=0,480$ it can be concluded that the QS affect the SAT

http://ojs.unud.ac.id/index.php/eot amounted to $48.0 \%$.

QS significantly affect LOY seen from the value sig $(0,000)<0,05$. QS strength directly affects LOY can be seen from $\beta$ (coefficient beta) is $0,503^{2}=0,253$ thus directly affect QS influence LOY amounted to $25.3 \%$.

SAT significantly affect LOY sig $<0,05$ and directly SAT affect LOY = $0,374^{2}=0,140$ thus SAT affecting LOY amounted $25,3 \%$. Effect of SAT outside the QS is equal to $100-48,0 \%=52 \%$.

Effect of QS against LOY through SAT $=13.2 \%$ as well as SAT influence on LOY through QS by $13.2 \%$., whereas the effect of QS totally against LOY $=25,3+$ $13,2=38,5 \%$.

SAT influence in total against LOY $=14,0$ $+13,2=27,2 \%$.

The power of QS \& SAT affect LOY total was $38,5+27,2=65.7 \%$. Received LOY influence from the outside in addition to QS \& SAT amounted to 100 $-65.7=34,3 \%$.

The comparison between QS and the SAT in terms of strength LOY influence can be seen from the $\mathrm{t}$ value, because the value $\mathrm{t}$ value QS $\rightarrow$ LOY $(0,574) \&$ SAT $\rightarrow$ LOY $(3,995)$ QS in influencing LOY, means that the strength of LOY was greater than SAT.

The results of path analysis which is to determine the quality of service and intervening variables, namely the satisfaction of tourists, as well as the dependent variable tourists' loyalty showed as follows :

a. Effect of quality of service to the satisfaction of tourists

Variable quality of service to customers satisfaction obtained $t_{\text {value }}>t_{\text {table }}(9.521>$ $1.984)$ and significance $0.000<0.05$. Then Ho is rejected and Ha accepted, which means there is a significant influence on satisfaction of service quality rating;

e-ISSN: 2407-392X. p-ISSN: 2541-0857 
b. The influence of the quality of service to the loyalty of travelers

Variable quality of service to travelers loyalty obtained $t_{\text {value }}>t_{\text {table }} \quad(5.754>$ $1.984)$ and significance $0.000<0.05$. Then Ho is rejected and Ha accepted, which means no significant effect on loyalty service quality rating;

c. The influence of satisfaction on loyalty rating

Variable traveler satisfaction on loyalty rating obtained $t_{\text {value }}>t_{\text {table }} \quad$ (3.995> $1.984)$ and significance $0.000<0.05$. Then Ho is rejected and Ha accepted, which means no significant effect on loyalty traveler satisfaction rating;

d. Influence $\epsilon 1$ of other variables apart from $\mathrm{X}$ to $\mathrm{Z}$

$=\sqrt{ } 1-\mathrm{R},=\sqrt{ } 1-0.693,=\sqrt{ } 0,307,=$ 0.554 or $55.4 \%$

e. Influence $\epsilon 2$ of other variables apart from $\mathrm{X}$ to $\mathrm{Y}$

$=\sqrt{ } 1-\mathrm{R},=\sqrt{ } 1-0.503,=\sqrt{ } 0,497,=$ 0.704 or $70.4 \%$

From the Table 1 can be seen that the path coefficient were as follows:

a. $\mathrm{QS} \rightarrow \mathrm{SAT}=0,693^{2}=0,480\left(\mathrm{r}^{2}\right)$

b. $\mathrm{QS} \rightarrow \mathrm{LOY}=0,503^{2}=0,253\left(\mathrm{r}^{2}\right)$

c. $\mathrm{SAT} \rightarrow \mathrm{LOY}=0,374^{2}=0,140\left(\mathrm{r}^{2}\right) \rightarrow$

The direct effect between variable $=r^{2}$ $=$ coefficient of beta ${ }^{2}$

Effect of a variable if influenced by other variables (QS \& SAT) to LOY was:

a. QS to LOY through SAT $=0,503 \mathrm{x}$ $0,693 \times 0,374=0,132$

b. SAT to LOY through $\mathrm{QS}=0,379 \mathrm{x}$ $0,693 \times 0,503=0,132$

Effect of total variable exsogen with other endogen variables $=$ direct effects + influence through other exogenous variables, were as follows:

a. Effect of QS to LOY total $=0,253+$ $0,132=0,385$

b. SAT influence to LOY total $=0,140+$ $0,132=0,272$
The results indicated that the quality of service of Bromo Tourism in East Java were quite reliable in providing convenience for tourists. They provide a friendly greeting and informing tourist sites and a safe parking location for tourists. The results also showed that admission price was relatively affordable which was only Rp. 27,500 - person. In addition, the quality of services were good with the information given by the officer when they ask about the location or existing panoramas. Lastly, satisfaction services perceived by the domestic tourists was also good at the Mount Bromo.

\section{Conclusion}

The quality of tour services significantly influenced domestic tourists' satisfaction, the quality of service also significantly influenced domestic tourists' loyalty and domestic tourists' satisfaction significantly influenced domestic tourists' loyalty at Mount Bromo East Java. The results indicated that there were positive perception of domestic tourists on the quality of tour services, satisfaction and loyalty at Mount Bromo.

\section{Suggestion for the future research}

Further research need to be focused especially on how management of tourism at Mount Bromo in East Java pay more attention and improve the quality of service to provide better facilities and services.

\section{Limitations of Research}

Research was not undertekan based on the varieties of seasons, such as low season and peak season. So that, it would be better if the research was also analyzed based of these variaties of seasons. 


\section{References}

Bloemer, J., De Ruyter, K. and Peeters, P. (1998) 'Investigating drivers of bank loyalty: the complex relationship between image, service quality and satisfaction', International Journal of bank marketing. MCB UP Ltd, 16(7), pp. 276-286.

Camarero, C. (2007) 'Relationship orientation or service quality? What is the trigger of performance in financial and insurance services?', International Journal of Bank Marketing. Emerald Group Publishing Limited, 25(6), pp. 406-426.

Gounaris, S. P., Stathakopoulos, V. and Athanassopoulos, A. D. (2003) 'Antecedents to perceived service quality: an exploratory study in the banking industry', International journal of bank marketing. MCB UP Ltd, 21(4), pp. 168-190.

Gustafsson, A. and Jhonson, M. D. (2000) 'Determining Atribute Importance in an Service Satisfaction Model', Journal of Service Research, 7(2), pp. 124-141.

Gwinner, K. P., Gremler, D. D. and Bitner, M. J. (1998) 'Relational benefits in services industries: the customer's perspective', Journal of the academy of marketing science. Sage Publications Sage CA: Thousand Oaks, CA, 26(2), pp. 101-114.

Han, H. and Back, K.-J. (2008) 'Relationships among image congruence,consumption emotions, and customer loyalty in the lodging industry', Journal of Hospitality \& Tourism Research. SAGE Publications, 32(4), pp. 467-490.
Harris, L. C. and Goode, M. M. H. (2004) 'The four levels of loyalty and the pivotal role of trust: a study of online service dynamics', Journal of retailing. Elsevier, 80(2), pp. 139-158.

Hennig-Thurau, T. and Klee, A. (1997) 'The impact of customer satisfaction and relationship quality on customer retention: A critical reassessment and model development', Psychology \& marketing. Wiley Online Library, 14(8), pp. 737-764.

Kotler, P. (2003) Marketing insights from A to Z: 80 concepts that must be understood by every manager. Jakarta: Erland.

Moliner, M. A., Sánchez, J., Rodríguez, R. M. and Callarisa, L. (2007) 'Perceived relationship quality and post-purchase perceived value: An integrative framework', European Journal of Marketing. Emerald Group Publishing Limited, 41(11/12), pp. 1392-1422.

Oliver, R. L. (1999) 'Whence consumer loyalty?', the Journal of Marketing. JSTOR, pp. 33-44.

Oliver, R. L. and DeSarbo, W. S. (1988) 'Response determinants in satisfaction judgments', Journal of consumer research. The Oxford University Press, 14(4), pp. 495507.

Prayitno, D. (2010) Understanding statistical data analysis. Yogyakarta: MediaKom.

Taroepratjeka, A. (2000) Making tourism more sustainable. Yogyakarta: Liberty. 